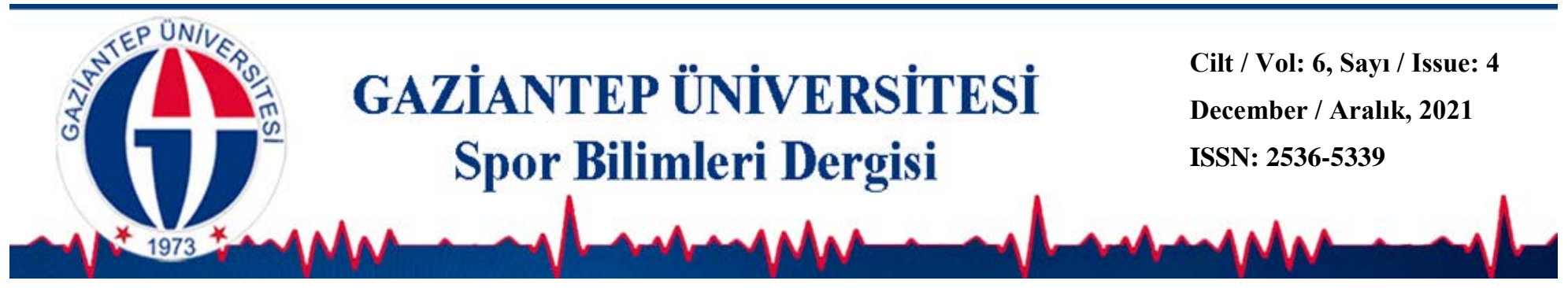

\title{
Spor Turizminin Türkiye Açısından Ekonomik Boyutu
}

\author{
Savaş DUMAN ${ }^{1}$ iD \\ Hacı Murat ŞAHIN ${ }^{1}$ \\ Çilem BULUT ${ }^{1 *}$ iD \\ ${ }^{1}$ Adnan Menderes Üniversitesi Spor Bilimleri Fakültesi, AYDIN \\ ${ }^{2}$ Çanakkale Onsekiz Mart Üniversitesi, Ayvacık Meslek Yüksekokulu, ÇANAKKALE
}

Ender Ali ULUÇ² iD

do:DOI: 10.31680/gaunjss.1018736

Orijinal Makale / Original Article

Geliş Tarihi / Received: 11.08.2021～Kabul Tarihi / Accepted: 29.11.2021Ｙayın Tarihi / Published: 24.12.2021

\section{Öz}

Turizm endüstrisi, günümüz koşullarında küresel ekonomi içerisinde önemli bir yere sahiptir. Kişilerin gündelik hayatlarında yer alan egzersiz yapma alışkanlıklarının veya yaşam tarzlarının dışında gittiği yerlerde karşılaştığı yeni spor dallarıyla tanışması ve seyahat dönüşü bu sporlara devam etme alışkanlıkları kazanması itibariyle spor ve turizm yoğun bir ilişki içerisine girer. Özellikle küresel çapta etkiye sahip olan spor organizasyonlarının spor turizmi içerisindeki etkisiyle; organizasyonu düzenleyen ülkenin tanıtımına, ekonomik kalkınmasına, istihdam alanlarının yaratılmasına, ticari faaliyetlerine, spora olan ilginin artmasına, ülkenin saygınlık kazanmasına olumlu katkılar sağlayacağı kamuoyu tarafından bilinmekte ve bundan dolayı ülkeler bu tür organizasyonlara ev sahibi olabilmek için kıyasıya bir yarışın içerisine girmektedirler. Türkiye'de turizm sektörü bacasız bir sanayi olarak görülmekte ve bu sektör Türkiye için önem arz etmektedir. Ülkedeki sportif etkinliklerin çeşitliliğinin gün geçtikçe artması, ulusal basının bu konuya ilgi göstermesi sayesinde kendi kültürünü tüm dünyaya aktarma şansı, spordaki profesyonellik olgusunun gelişmesi, kitle sporunun gelişmesi ve ülkenin belirli bölgelerindeki sportif üretkenlik, spor turizmi alanında sağlanan önemli gelişmeler arasında yer almaktadır. Spor turizminin Türkiye açısından ekonomik boyutunun incelenmesi amacıyla yapılan bu araştırmada; Spor turizmi konusunda yapılan çalışmalar doküman analizi yöntemiyle incelenmiştir. Sonuç olarak; Sporun ve turizmin birbirine entegre kavramlar olduğu, turizmde meydana gelen her bir olayın spor turizmini etkiyebileceği gibi ülke ekonomisini de etkilediği sonucuna ulaşılmıştır. Anahtar Kelimeler: Turizm, Spor, Spor Turizmi, Ekonomi.

\section{Economic Dimension of Sports Tourism for Turkey}

\section{Abstract}

The tourism industry has an important place in the global economy in today's conditions. Sports and tourism enter into an intense relationship as people meet new sports branches, they encounter outside of their daily exercise habits or lifestyles and gain the habit of continuing these sports after travel. Especially with the effect of sports organizations that have a global impact in sports tourism; It is known by the public that the organization will contribute positively to the promotion, economic development, creation of employment areas, commercial activities, increased interest in sports and the country's prestige, and therefore, countries are in a fierce race to host such organizations. The tourism sector in Turkey is seen as a smokeless industry and this sector is important for Turkey. The increase in the diversity of sports activities in the country day by day, the chance to transfer their own culture to the whole world thanks to the national press's interest in this issue, the development of professionalism in sports, the development of mass sports and sportive productivity in certain regions of the country are among the important developments in the field of sports tourism. In this research, which was conducted to examine the economic dimension of sports tourism in terms of Turkey; Studies on sports tourism have been examined by document analysis method. As a result; It has been concluded that sports and tourism are integrated concepts, and each event that occurs in tourism can affect sports tourism as well as affect the country's economy.

Keywords: Tourism, Sports, Sports Tourism, Economy.

\footnotetext{
*Sorumlu Yazar: Çilem BULUT

e-mail: bulutcilem0@gmail.com

**Bu araştırma V. Uluslararası Akademik Spor Araştırmaları Kongresinde Sözel Bildiri Olarak Sunulmuştur
} 
Duman S, Şahin HM, Uluç EA, Bulut Ç. (2021). Spor Turizminin Türkiye Açısından Ekonomik Boyutu. Gaziantep Üniversitesi Spor Bilimleri Dergisi, 6(4), 367-383.

\section{Giriş}

Insanların dinlenme, eğlenme, çalışma ve diğer gayelerle sabit kaldıkları mekânların ötesine kazanç sağlama amacı içindeki eylemlere bağlı olmaksızın ve bir yıldan fazla uzun sürmeyecek biçimde gezintiye çıkmalarından ve konaklamalarından meydana gelen etkinliklere turizm adı verilmektedir (Çuhadar, 2006).

Turizm; ekonomik, toplumsal ve kültürel yaşamı pozitif yönde etkileyerek doğal güzellikleri ve yaşam alanlarını korumuş ve bu yönüyle insanlara olumlu yönde mesajlar vermiştir (Özdemir, 2020). Turgut (2019)'a göre, özellikle genç nüfusa sahip olan ülkelere istihdam alanı yaratarak, yerli ve yabancı turistlere sunduğu cazip tekliflerle ülkelerin ekonomisine kayda değer katkılar sunmaktadır. I. Dünya ülkelerinde çalışma sürelerinde meydana gelen azalma ile birlikte serbest zaman etkinliklerinin artış göstermesi, insanların başka diyarları görmek ve geleneklerini tanımak istemeleri, turizmin hız kazanmasında etkili olmuştur (Usta, 2009). Turizm alanında meydana gelen değişimler, küresel düzeyde turizm kazançlarını da olumlu yönde etkileyerek kişi başına düşen milli gelirin de artış göstermesine imkân tanımaktadır. Rahmalaroğlu (2009)'na göre, spor ve turizm ortak kökenli ve yakından ilişkili sosyal olgulardır. Peric (2010)'e göre; turizm, deneyim odaklı bir faaliyet iken spor performans odaklı bir aktivite olarak görülmektedir. Böylelikle bu iki olgu birbirini tamamlayabilmektedir.

Turizm; yaşadığımız dönem içerisinde endüstriyel faaliyetlerin başında önemli bir yere sahiptir. Spor ise, çağımızın en geniş toplumsal olgusu olarak görülmektedir. Dolayısıyla turizm ve spor arasındaki etkileşimin artması, her iki endüstrinin de gelişmesi için son derece önemlidir. (Kurtzman ve Zauhar, 2003). Dünya Turizm Örgütü'nün verilerine göre, turizm sektörü 2016 yılı itibariyle 1,3 trilyon dolar gibi bir büyüklüğe ulaşmıştır. Spor turizminin turizm sektöründen aldığı pay ise, 200 milyar dolar olarak hesaplanmaktadır. Küresel turizmin büyüme oranı yıllık \%4 ila \%5 seviyelerinde seyrederken, spor turizminde bu rakam \%10'lara kadar çıkmaktadır. Aynı şekilde uluslararası verilere bakıldığında, spor turistinin normal bir turiste nazaran yaklaşık 2 kat daha fazla harcama yaptığı görülmektedir (Türkiye Seyahat Acenteleri Birliği, 2015; Kuburlu, 2017). Bu doğrultuda, spor turizminin Türkiye açısından ekonomik boyutunun incelenmesi bu araştırmanın amacını oluşturmaktadır

\section{Turizm Kavramı}

Orel ve Yavuz (2003)'a göre, bireylerin, kişisel doyum amacıyla, özgür iradeleri ve arzuları doğrultusunda, herhangi bir maddi çıkar gözetmeksizin, sürekli olarak yaşadıkları bölgeden kısa süreliğine ayrılarak, yapmış oldukları faaliyetlere turizm adı 
Duman S, Şahin HM, Uluç EA, Bulut Ç. (2021). Spor Turizminin Türkiye Açısından Ekonomik Boyutu. Gaziantep Üniversitesi Spor Bilimleri Dergisi, 6(4), 367-383.

verilmektedir. Barutçugil (1989)'e göre, bireylerin tüketici olarak yapmış oldukları seyahatler ve geçici olarak belirli bir bölgede konaklamaları turizmin kapsamı içerisinde değerlendirilmektedir. Bireysel veya kitleler halinde gerçekleştirilen turizmde ülke vatandaşlarının kendi ülkesinde bulunan bir bölgeye yaptıkları seyahatler; iç turizm olarak değerlendirilirken, yabancı bir ülkeye yapılan seyahatler dış turizm olarak değerlendirilmektedir (Holloway, Humphreys ve Davidson, 2009).

Günümüzde turizm endüstrisi küresel ekonomi içerisinde önemli bir yere sahiptir. Güdük (2019)'e göre, bu faaliyetlerin gerçekleştirilmesinde rol oynayan paydaşlar ve bu paydaşların birbirleriyle olan ilişkileri, turizm endüstrisini oluşturmaktadır. Turizmde meydana gelen ekonomik büyüklük dolaylı olarak hareketlenme sağlayarak birçok sektörü de etki altına almaktadır. Can (2020)'a göre, turizm sektörü her ne kadar sosyal ve kültürel yönü olan bir olay ve ilişkiler bütünü olsa da ülkelere sağladığı ekonomik faydaları yadsınamaz ölçüdedir. Kapitalist dünya düzeninin olduğu günümüzde, sektörler esas olarak ekonomik etkileriyle ele alınmakta ve öncelikli olarak bu yönüyle değerlendirilmektedir. Dünya Seyahat ve Turizm Konseyinin (World Travel and Tourism Council) 2018 yılında yayınlamış olduğu rapora göre; turizm endüstrisinden elde edilen gelir 8,27 katrilyon dolar seviyesindedir. Bu rakam, dünya genelindeki gayri safi milli hasılanın \%10,4'ünü oluşturmaktadır. Ayrıca, turizm endüstrisinde çalışanlar küresel iş gücünün \%9,9'unu oluşturmaktadır (Dünya Turizm Konseyi, 2018).

\section{Turizmin Ülke Ekonomisinde Yeri ve Önemi}

Turizm sektörü; işsizlik seviyesinin düşmesine olanak tanıdığı gibi, bölgeler arası ekonomik dengesizlikleri düzenleyerek, ülkelere dövizin girişine de olanak tanımaktadır (Özcan, 2021). Ayrıca, turizm birçok sektöre de ekonomik açıdan fayda sağlamaktadır (Dilber, 2007; Arabacı, 2018). Baykul ve Maden (2017)'e göre; turizm, belirli bir toplum içerisinde yaşayan insanların refah düzeylerinin artmasını sağladığı gibi ekonomik açıdan da büyüme sağlamaktadır. 2019 yılında Dünya Turizm ve Seyahat Konseyinin verileri doğrultusunda Turizm Dünya Gayri Safi Yurtiçi Hasılasına 8,9 trilyon \$ katkı sağlamıştır. Sağlanan bu katkı Gayri Safi Yurtiçi Hasılanın yaklaşık olarak 10,3'ünü oluşturmaktadır. Yine aynı dönem içerisinde turizm sektörü 330 milyon kişiye istihdam olanağı sağlamıştır. Bu olanak dünya geneline göre incelendiğinde her 10 kişiden birinin turizm sektöründe çalışığını göstermektedir. 2019 yılında yapılan sermaye yatırımları incelendiğinde \%4,3'ünün turizm kaynakları olduğu görülmektedir (Dünya Turizm ve Seyahat Acenteleri Konseyi, 2020). Türkiye'de turizm sektörü 
Duman S, Şahin HM, Uluç EA, Bulut Ç. (2021). Spor Turizminin Türkiye Açısından Ekonomik Boyutu. Gaziantep Üniversitesi Spor Bilimleri Dergisi, 6(4), 367-383.

bacasız bir sanayi olarak görülmekte ve bu sektör Türkiye için önem arz etmektedir. Şahbaz ve Mızrak (2017)'a göre, ekonomik büyümenin devamlılı̆ının sağlanması ülkemiz açısından kritik bir yere sahiptir.

Dünya Bankası veri tabanı (2020)'na göre, Ülkelere göre ziyaretçi sayısı ve turizm gelirleri şu şekildedir;

Tablo 1. Ülkelere göre ziyaretçi sayısı ve turizm gelirleri

\begin{tabular}{|l|l|l|l|}
\hline \multicolumn{1}{|c|}{ Ülke } & \multicolumn{1}{|c|}{$\begin{array}{c}\text { Ziyaretçi Sayısı } \\
\text { (Milyon Kiși) }\end{array}$} & \multicolumn{1}{|c|}{$\begin{array}{c}\text { Turizm Geliri } \\
\text { (Milyar \$) }\end{array}$} & \multicolumn{1}{c|}{ Turizm Geliri/ } \\
Ziyaretçi Sayısı (\$)
\end{tabular}

Kaynak: Dünya Bankası Veri Tabanı (2020).

Tablo 1 incelendiğinde, ziyaretçi sayısının en fazla olduğu ülkelerin başında Fransa gelirken Türkiye'nin en fazla ziyaretçi alan 5. ülke olduğu görülmektedir. Ziyaretçi sayınının en az olduğu ülke Malezya'dır. Ülkelere göre turizm gelirleri incelendiğinde; en fazla gelire sahip ülkenin ABD olduğu görülmektedir.

Dünya Bankası veri tabanı (2020)'na göre, ülkelere göre turizm gelirleri ve ziyaretçi sayıları şu şekildedir; 


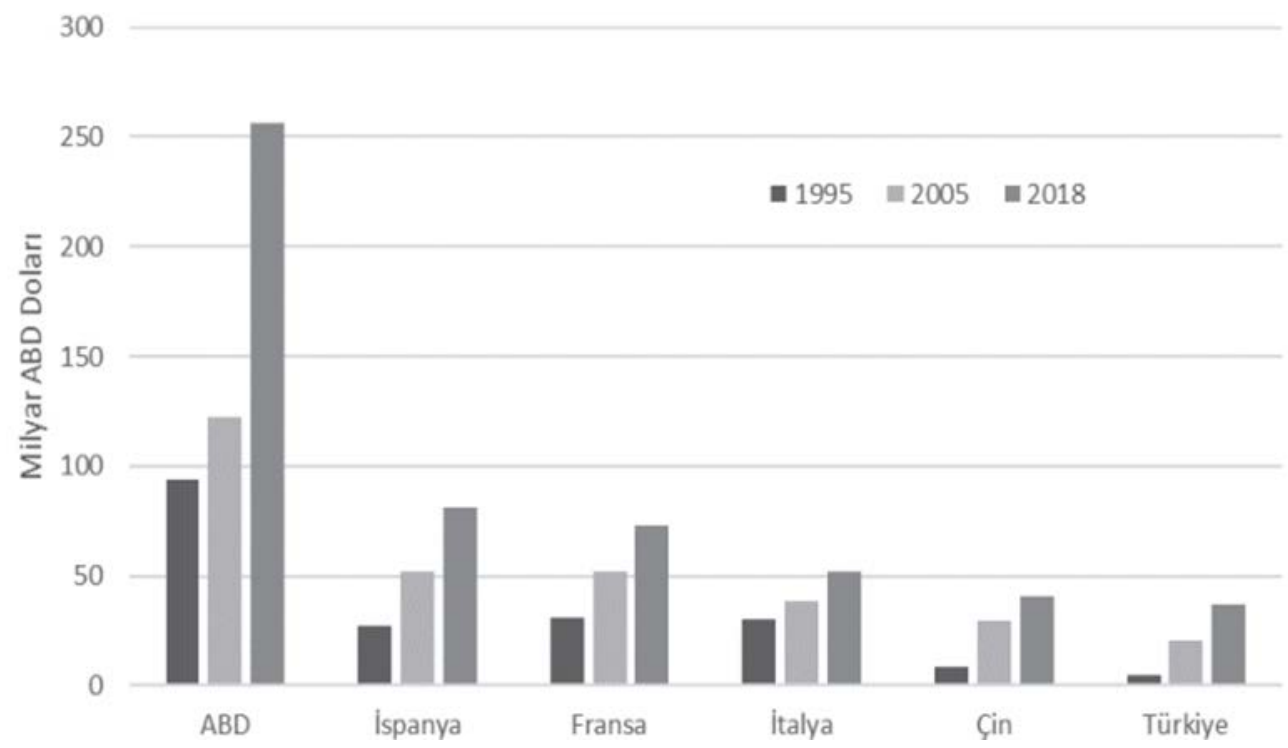

Şekil 1. Ülkelere göre turizm gelirleri

Birçok ülkenin ekonomisinde önemli bir yere sahip olan turizm sektörü her ülke için kritik bir role sahiptir. Dünya bankasına göre, küresel ölçekte 86 trilyon \$'lık katma değerin 1,6 trilyon \$'ık kısmı turizmden elde edilmiştir.

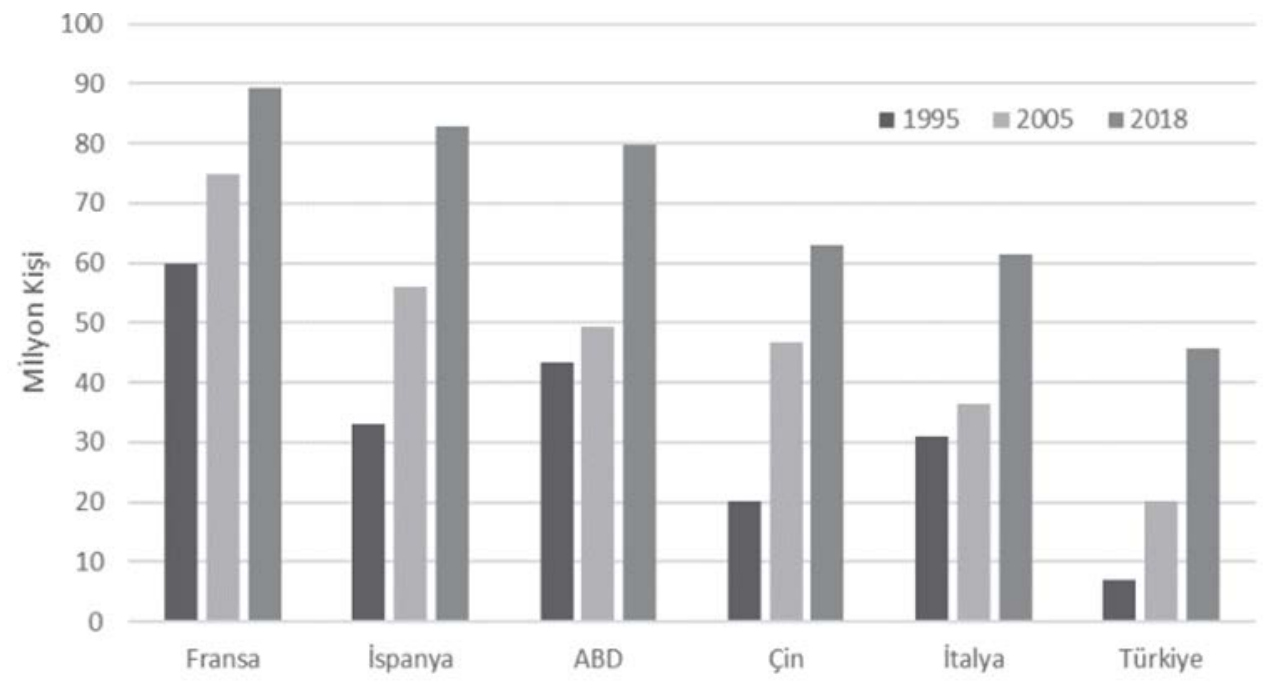

Şekil 2. Ülkelere göre ziyaretçi sayısı

Şekil 2 incelendiğinde; 2018 yılında ABD, İspanya ve Fransa'nın ziyaretçi sayılarının birbirlerine yakın olduğu görülmektedir. Ziyaretçi sayıları Türkiye açısından incelendiğinde, sürekli olarak artış gösteren bir grafik olması dikkat çekidir. Insanların Turizm Faaliyetlerine Katılma Sebepleri

Özdemir (2020)'e göre, İnsanların turizm aktivitelerine katılmak istemelerindeki etkenler yerli ve yabancı turistlerin gereksinim ve beklentilerine göre farklılık 
Duman S, Şahin HM, Uluç EA, Bulut Ç. (2021). Spor Turizminin Türkiye Açısından Ekonomik Boyutu. Gaziantep Üniversitesi Spor Bilimleri Dergisi, 6(4), 367-383.

gösterebilmektedir. Turistlerin bazıları bir amaç uğruna bazıları ise birden fazla amaç uğruna turizm organizasyonlarına katılabilmektedir İnsanların turizm faaliyetlerine katılma sebepleri şekil 3'te gösterilmektedir.

İnsanların Turizm Faaliyetlerine Katılmak İstemelerindeki Etkenler

\begin{tabular}{|l|}
$*$ Eğlence ve Hoşça \\
Vakit Geçirme \\
* İs ve Kongre \\
Seyahatleri \\
\end{tabular}

* Sağlık

* Spor

* Dini Nedenler

Şekil 3. Inssanların turizm faaliyetlerine katılma sebepleri. Kaynak: Turgut (2019).

Yerli ve yabancı turistlerin başlıca beklentisi turizm etkinliklerine katılmak için gittikleri ülkelerin eğlenebileceği ve hoşça vakit geçirebileceği şartlara sahip olmasıdır (Usta, 2009). Gelişmekte olan ülkelerde ise insanlar; çalışma koşullarının ağırığı, çalışma saatlerinin fazlalığı, çevre ve gürültü kirliliğinden kurtulmak, rahatlamak ve eğlenmek gibi nedenlerden dolayı turizm faaliyetlerine katıım göstermektedirler (Özdemir, 2020). Var olan dinlerin birçoğunda senenin belirli dönemlerinde tören niteliğinde ibadetler yapılmaktadır. Kutsal kabul edilen yerler inanca göre değişiklik göstermektedir. İnsanlar ibadetlerini gerçekleştirmek kutsal mekânlara ulaşmak için yolculuğa çıkmaktadır. Hac yolculuğu ise bunlar arasında en çok ilgi duyulan ve artarak devam eden turist hareketini meydana getiren bir olaydır (Usta, 2009).

İnsanların intisas gerektiren bilimsel alanlarda belirli bir konuda fikir alışverişinde bulunmak maksadıyla düzenledikleri turizm türü iş ve kongre seyahatleri içerisinde yer almaktadır. Başka bir tanımda ise bireylerin sabit olarak kaldıkları mekanların dışında intisas gerektiren, sistematik alanlarda veya iş kollarında, belli bir konuda fikir alışverişi yapmak maksadıyla bir araya gelmeleri sonucu oluşan gezinti, konaklama, olgu ve alakaların kongre ve iş seyahatleri amacıyla yapılan turizmin içerisinde yer almaktadır (Aymankuy, 2013). Turistik kongre, düzenlendiği şehrin reklamını ve markalaşmasını sağlayıp saygınlık kazandırıken o bölgenin kamusal sahadaki başarısının simgesi olmasıyla birlikte sezon sonu istihdamında sağlanmasına olanak tanımaktadır (Zengin, 2006). İnsanlar geçmişten günümüze sıhhat içinde yaşayabilmek, hastalıklarına şifa 
Duman S, Şahin HM, Uluç EA, Bulut Ç. (2021). Spor Turizminin Türkiye Açısından Ekonomik Boyutu. Gaziantep Üniversitesi Spor Bilimleri Dergisi, 6(4), 367-383.

aramak için yolculuk etmektedirler (Özdemir, 2020). Bu durum sağlık amaçlı yapılan turizmin içerisinde yer almaktadır.

Tüm bunların yanında bireyleri turizme yönlendiren bir değer etken ise spordur. Spor; insanların geçmiş dönemlerden günümüze bilinçli olmadan yaptığı spor hareketleri, fiziksel ve ruhsal olarak yenilenmesine ve gelişmesine yardımcı olan bir bilim dalıdır (Aracı, 1999). Vücudun tüm niteliklerini geliştirmek için gereken etkinlik spordur. Bir başka tanımda ise spor; kendine güven, yaratıcı olma, rekabet, eğlenme, sıhhat, faaliyet, formda olma ile yeteneklerini üst seviyeye çıkarmak maksadıyla gerçekleştirilen bir olayı ifade etmektedir (Grössing, 1991). Günümüzde insan hayatının vazgeçilmezi olan spor, turizm ile birleşerek önemli bir alan oluşturmaktadır. Insanlar meydana gelen bu turizm faaliyetine aktif veya pasif olarak katılım sağlamaktadırlar. Spor ve turizm faaliyetlerinin düzenlendiği ülkelerde ekonominin iyileşmesi ve tanıtımının yapılması sonucunda spor turizmine yapılan yatırımlar artarak devam etmektedir. Bilhassa ülkelerin spor turizminden politik, iktisadi, kültürel, reklam yönünden faydalandığı söylenebilir (Turgut, 2019).

\section{Spor Turizmi}

Toromanlı (2014)'ya göe spor turizmi kavramı dendiğinde insanların aklına birkaç farklı dalda spor yapmanın yanında tek bir sporu yapmak amacıyla da yapılan seyahatler gelmektedir. Farklı dallarda spor yapmayı kapsayan "spor turizmi” yanında spor turizmi türlerinin alt dallarının gelişimine olanak tanımıştır (Hazar, 2007). Gibson (1998) spor turizmini; aktif spor turizmi, olay tabanlı spor turizmi ve nostalji spor turizmi olarak 3 bölüme ayırmıştır. Aktif spor turizmini; sportif faaliyetlere katılan veya rekabet etmek amacıyla gezintiye çıkan sporcular ve dinlenme dönemlerinde rekreasyon faaliyetleri olarak gittikleri çevrelerde spor işletmelerinden faydalanmak için gezintiye çıkanlar oluştururken, olay tabanlı spor turizmini dünya şampiyonaları ve kıtalarda gerçekleşen spor organizasyonu gibi etkinliklere katılmak için gezintiye çıkanlar, nostalji spor turizmini geçmişten günümüze kazanılan başarıların gerçekleştiği stadyumları, salonları vb. mekanları ve müzeleri görmek için gezintiye çıkanlar olarak ifade etmiştir.

Spor, turizme katılım esnasında kişilerin gündelik hayatlarında yer alan egzersiz yapma alışkanlığının, davranışının veya hayat tarzının dışında gittiği noktalarda karşılaştığı yeni spor dallarıyla tanışarak seyahat dönüşü bu sporlara devam etme alışkanlıkları kazanması itibariyle turizmle yoğun bir ilişki içerisine girer ve böylelikle birbirlerine karşılıklı olarak seyahat eden kitlenin miktarı ve niteliği ile orantılı bir şekilde 
Duman S, Şahin HM, Uluç EA, Bulut Ç. (2021). Spor Turizminin Türkiye Açısından Ekonomik Boyutu. Gaziantep Üniversitesi Spor Bilimleri Dergisi, 6(4), 367-383.

katkı sağlar (Yeşil, 2015). Ülkedeki sportif etkinliklerin sayısının gün geçtikçe artması, ulusal basının bu konuya ilgi göstermesi ve bu ilginin artması sayesinde kendi kültürünü tüm dünyaya aktarma şansı, spordaki profesyonellik olgusunun gelişmesi, kitle sporunun gelişmesi ve ülkenin belirli bölgelerindeki sportif üretkenlik bu konuda sağlanan önemli faydalardan bazılarıdır (Miçoğulları, 2004).

\section{Spor Turizminin Popüler Olma Nedenleri}

Güdük (2019)'a göre Türkiye'de spor turizminin gelişmesinde üç ana unsur bulunmaktadır. Bu unsurlardan ilki, ev sahipliği yapılan uluslararası organizasyonlardır. 1997 Dünya Hava Sporları ve 1999 Avrupa Yüzme Şampiyonası'na ev sahipliği yapan Türkiye zaman içinde ev sahipliği yaptığı uluslararası organizasyon sayısını arttırmıştır. 17. Akdeniz Oyunları, 25. Dünya Üniversiteler Kış Oyunları, FIFA U20 Dünya Kupası, Cumhurbaşkanlığı Türkiye Bisiklet Turu, 2017 Dünya İşitme Engelliler Olimpiyatları, Uluslararası İstanbul Maratonu bu organizasyonlardan bazılarıdır. İkinci unsur, 20-25 yıl kadar önce rafting, yamaç paraşütü gibi sporların Türkiye'de spor turizmi kapsamında değerlendirilmeye başlanıp hızla yaygınlaşmasıdır. 2000'li yıllara geldiğimizde de Türkiye'de spor turizminin gelişimindeki en önemli unsur olan futbol kamp turizmi ve golf turizmi karşımıza çıkmaktadır. Özellikle, Antalya'nın Belek beldesi spor turizmi konseptli otelleriyle adından söz ettirmektedir (Karakoç, 2011).

Tablo 2. Spor Turizmi Çeşitlerinden bazıları

\begin{tabular}{|l|l|l|l|}
\hline Doğa Sporları & Hava Sporları & Su Sporları & Kış Sporları \\
\hline Doğa Yürüyüşü & Yamaç Paraşütü & Rafting & Kayak \\
\hline Dağcılık & Yelken Kanat & Dalış & Curling \\
\hline Bisiklet & Balon & Sörf & Buz Hokeyi \\
\hline Avcılık & Paraşüt & \multicolumn{2}{|l}{} \\
\cline { 1 - 3 } Oryantiring & \multicolumn{2}{|l}{} \\
\cline { 2 - 3 }
\end{tabular}

\section{Spor Turizminin Ülke Ekonomisine Katkıları}

Özdemir (2020)'e göre, spor organizasyonlarının turizmin kalkınmasında ve markalaşmasında pek çok etkisi bulunmaktadır. Bunların en önemlilerinden bir tanesi de işin ekonomik boyutudur. Spor turizminin kâr getirici özelliğinin olması, iş alanlarının çoğalması ile ülkeler arasında ticari ilişkilerin artması gibi pek çok olumlu etkileri bulunmaktadır (Stephen, 2001). Gelişmekte olan ülkelerde yeni iş kollarının açılmasına, altyapı, ulaşım, iletişim gibi alanların daha ileri seviyelere ulaşmasında önemli katkı sağlayacağı öngörülmektedir (İçöz ve Kozak, 2002). Spor turizminin iktisadi etkileri; yerel ve küresel organizasyonlar sayesinde dünyanın her bir 
Duman S, Şahin HM, Uluç EA, Bulut Ç. (2021). Spor Turizminin Türkiye Açısından Ekonomik Boyutu. Gaziantep Üniversitesi Spor Bilimleri Dergisi, 6(4), 367-383.

köşesinden önemli iş insanlarını, gazetecileri, sporcuları ve sporseverlerini bir araya getirmekte yaptıkları harcamalar sayesinde ülkeye döviz girdisi olmakta ve ülkenin tanıtımında etkin rol oynamaktadırlar (Şebin, 2018). Özellikle küresel çapta etkiye sahip olan spor organizasyonlarının spor turizmi içerisindeki etkisiyle organizasyonu düzenleyen ülkenin tanıtımına, ekonomik kalkınmasına, istihdam alanlarının yaratılmasına, ticari faaliyetlerine, spora olan ilginin artmasına, ülkenin saygınlık kazanmasına olumlu katkılar sağlayacağı kamuoyu tarafından bilinmekte ve bundan dolayı ülkeler bu tür organizasyonlara ev sahibi olabilmek için kıyasıya bir yarışın içerisine girmektedirler (Gündoğdu, 2001).

Spor turizmi, küresel ekonomiye büyük katkılar sağladığı gibi, ülkeler ve yerel ekonomiler için de ekonomik kalkınma aracı olarak görülmektedir. Schneider Publishing'in Sports Travel Magazine'in okurlarına dayanarak gerçekleştirdiği bir araştırmada, spor ile ilgili seyahat ve turizmin tek başına Amerika Birleşik Devletleri'nde 118,3 milyar dolarlık bir pazar yarattığı (Delpy, 1998), yine Avustralya'da gerçekleştirilen bir başka çalışmaya göre, spor turizminin, toplam turizm pazarının \%55'ini oluşturduğu ve yılda yaklaşık 3 milyar dolar tutarında bir ekonomik etki yarattığı hesaplanmıştır (Tourism Review News, 2010).

Rahmalaroğlu (2019)'a göre, bu denli önemli sonuçlar doğuran spor turizminin, kısa ve uzun vadede ülke ekonomisine birçok olumlu etkisi mevcuttur. Kısa vadede genelde üç tür etkiden bahsedilebilir bunlar:

Doğrudan etki: Spor turistinin spor etkinliğini izlemek için gittiği bölgede gerçekleştirmiş olduğu doğrudan harcamaların yarattığı istihdam, gelir artışı.

Dolaylı etki: Spor etkinliğinin düzenlenmesine katkıda bulunan diğer sektörlerin yapılmış olan bu harcamalardan elde ettiği gelir artışı ve istihdam.

Teşvik etkisi: Etkinlik için yapılan harcamaların bölge halkına kazandırdığı parada yarattığı artıştır. Spor turizminin ülke ekonomisine yarattığı uzun vadedeki ekonomik faydaları da azımsanmayacak kadar değerlidir.

Kasap ve Filiz (2008)'e göre, spor turizminin uzun vadedeki ekonomik etkileri; endüstrilerin oluşması, toplumun kültürel ve sosyal bakımdan gelişmesi ve ülkenin birebir reklamının yapılması şeklinde sıralanmaktadır. Turizm gelirlerinin yükseltilmesinde önemli alanlardan bir diğeri de spor turizmidir. Yılın tamamına yayılarak sezonun uzamasına vesile olan spor turizminin Türkiye'deki hacmi 1 milyar dolar düzeyindedir. Spor turizmi için gelenleri kişi başı ortalama harcama miktarı ise 2 bin dolar civarındadır. 10-14 gün gibi uzun konaklama ortalamasına sahip spor 
Duman S, Şahin HM, Uluç EA, Bulut Ç. (2021). Spor Turizminin Türkiye Açısından Ekonomik Boyutu. Gaziantep Üniversitesi Spor Bilimleri Dergisi, 6(4), 367-383.

turizminde golf ilk sırayı alırken onu futbol kampları ve diğer spor dalları izlemektedir. (Türkiye Seyahat Acenteleri Birliği, 2020).

\section{Türkiye'de Spor Turizmi ve Türkiye Ekonomisine Katkıları}

Türkiye, göreceli ve mutlak konumu itibarıyla turizm potansiyeli açısından önemli özelliklere sahiptir (Özdemir, 2020). Türkiye'nin ılıman kuşakta yer alması, güneşli gün sayısının çokluğu ve üç tarafının denizlerle çevrili oluşu kıyı turizmini geliştirmiştir (Dünya Atlası, 2018). Özdemir (2020)'e göre, son yıllarda sporun tüm branşlarına gereken değerin verilmesi ve her branşa ait spor tesislerinin inşa edilmesiyle birlikte spor turizm sektöründe ciddi bir talep yoğunluğu yaşanmaya başlanmıştır. Özellikle futbol, basketbol, voleybol, golf, tenis, yüzme, doğa sporları gibi spor branşlarıyla ilgili uluslararası organizasyonlar düzenlenmekte, böylece Türkiye'nin tanıtımına, ekonomik kalkınmasına, toplumsal paylaşımların artmasına ve politik ilişkilerin iyileşmesine katkılar sağlamaktadır. Türkiye Seyahat Acenteleri Birliği (2014) turizm raporuna göre; "Dünyada spor turizmin büyüklüğü 180 milyar dolar düzeyinde olduğu tespit edilmiş uluslararası hesaplamalarda ortaya çıkan ortalamalara göre spor turisti normal turistin 2 katı kadar harcama yapmakta Türkiye'ye gelen turistin ortalama harcaması 824 dolar olduğu açıklanmış buradan hareket edildiğinde spor amaçlı gelenlerin ortalama harcaması 1.648 doları bulmaktadır." Yine aynı raporda Türkiye'de spor yapan yabancı turistlerin sayısı 550 bini aşmış durumda bu turistlerin yaptığı harcamalar 900 milyon doların üzerine çıkmış, bir milyar dolar seviyesine yaklaştığı söylenebilir. Türkiye düzenlenen ve düzenlenecek olan uluslararası spor etkinlikleri baz alınarak hesaplanan Küresel Spor Endeksinde 14. sırada yer almaktadır. Düzenlediği etkinlik sayısı bakımından dünyada 18. sırada bulunmaktadır. Türkiye'de spor turizminin toplamdan aldığı pay yüzde 1,5 düzeyinde bulunurken söz konusu payın en büyük kısmını ise golf ve futbol oluşturmaktadır. Futbol turizminde ise hazırlık kamplarında yaklaşık 1.200 takım kamp yapmak için Türkiye'ye gelmektedir. Futbol kampı yapanların yarattığı direkt hacim ise 100 milyon doları aşmış durumdadır. Antalya'da kamp yapan futbol takımlarının yüzde 90'ını yabancılar oluştururken golf için gelenlerin sayısı 160 binin üzerine çıkmış bulunmaktadır. Türkiye'de bulunan 28 golf sahasının 21'i Antalya'nın Belek bölgesinde bulunmaktadır. Golf sporunu icra etmek için gelenleri çoğunlukla Almanlar oluştururken bunları İngiliz, İsveç ve Fransızlar takip etmektedir. Türkiye'de spor turizmi kapsamında küresel çapta etki yaratan en önemli müsabakalardan biri olan UEFA Şampiyonlar Ligi finali 2005 yılında İstanbul'da düzenlenmiştir. Milan ve Liverpool arasında oynanan futbol 
Duman S, Şahin HM, Uluç EA, Bulut Ç. (2021). Spor Turizminin Türkiye Açısından Ekonomik Boyutu. Gaziantep Üniversitesi Spor Bilimleri Dergisi, 6(4), 367-383.

karşılaşmasının İstanbul'a 390 milyon Euroluk ekonomik katkısı olmuştur. Dev finali 233 ülke canlı olarak yayınlamıştır. 2007 yılında ise, bir başka küresel etkiye sahip spor organizasyonu olan Formula 1 yarışları İstanbul Grand Prix'inde düzenlenmiştir. Türkiye'ye yarattığı ekonomik etkinin ise 400 milyon Euro'yu bulduğu açıklanmıştır. Ayrıca 203 ülke tarafından canlı yayınlanarak Türkiye'nin tanıtımına katkıları olmuştur. 2009 yılında ise, Shakhtar Donetsk -Werder Bremen arasında oynanan UEFA kupasının son finaline İstanbul ev sahipliği yapmıştır. Türkiye 90 milyon doları bulan salon yatııımları sonrasında 2010 yılında FIBA Erkekler Basketbol Şampiyonasına ev sahipliği yapmıştır. Maçların yapıldığı İstanbul, Ankara, İzmir ve Kayseri'de dünya genelinde büyük bir tanıtım imkânı elde etmiştir. Maçları izlemek için Türkiye'ye yaklaşık 30-40 bin civarında yabancı turist gelmiştir. Bununla birlikte 24 ülkeden basketbol takımlarının katıımıyla gerçekleşen şampiyonanın konaklama, ulaşım, bilet satışları, turist harcamaları, sponsorluklar, reklamlar ve operasyon kalemlerinde yapılan harcamaların Türkiye'ye yarattığı ekonomik katkısı 300 milyon TL olmuştur. Sportif başarı açısından baktığımızda Basketbolda 12 Dev Adam finalde Amerika Birleşik Devletleri ile karşılaşmış ve gümüş madalya kazanarak tarihi bir başarıya imza atmıştır. 2019 yılında Türkiye'nin Başkenti Ankara'da CEV Avrupa Kadınlar Voleybol Şampiyonası düzenlenmiş ve Filenin Sultanları Sırbistan ile karşılaşmış Avrupa ikincisi olarak gümüş madalya kazanmış ve tarihi bir başarıya imza atmıştır.

Sonuç olarak, Türkiye gibi sporla iç içe olan bir ülkede böylesi büyük spor organizasyonlarına ilginin artması ve sporseverlerin spor tesislerine akın etmesi beklenmektedir. İleriki yıllarda gelişerek ve yaygınlaşarak devam edeceğini umduğumuz, Türk sporu ve turizmi bu organizasyonlar sayesinde adından sıkça söz ettirecek ve büyümesini hızlandıracaktır. 2005 ve 2020 yılları arasında düzenlenmiş olan uluslararası spor organizasyonları sayesinde elde edilen tecrübe ve hemen hemen her ilde yapılan spor tesisleriyle daha büyük küresel etkiye sahip turnuvalara, olimpiyat oyunlarına ev sahipliği yapabileceğimiz aşikardır.

\section{Tartışma ve Sonuç}

Spor ve turizm kavramlarının entegrasyonuyla turizm endüstrisinin önemli bir parçasıdır (Taleghani ve Ghafary, 2014). Spor turizmi, dünyanın ve Türkiye'nin en önemli endüstrilerinden biri olan turizmin önemli bir öğesi konumundadır (Akyol ve Akkaşoğlu, 2021). Sportif aktiviteler, katılım gösteren bireylerin fiziksel ve kültürel gelişimlerine katkıda bulunmakta, turistik faaliyetler içerisinde değerlendirildiğinde ise keyif verici etkinlikler olabilmektedir (Alaeddinoğlu ve Komşu, 2017). Tüm bunların 
Duman S, Şahin HM, Uluç EA, Bulut Ç. (2021). Spor Turizminin Türkiye Açısından Ekonomik Boyutu. Gaziantep Üniversitesi Spor Bilimleri Dergisi, 6(4), 367-383.

yanında yapılan sportif aktiviteler her kesimde yaşayan bireylerde barış, anlayış ve hoşgörü duygularının ortaya çıkmasına imkan tanımaktadır.

Beyazgül, Karadeniz ve Güdük (2019) tarafından yapılan bir araştırmada, Futbol turizminin ekonomik etkileri incelenmiştir. Beyazgül ve diğerleri (2019) tarafından yapılan bu çalışmada, Dünya'da belirli aralıklara düzenlenen futbol turnuvalarından birine Türkiye'nin ev sahipliği yapabilmesi ve ülkeye daha fazla turist çekilebilmesi amacıyla, Türkiye'deki futbol kulüpleri ve Türkiye futbol milli takımının uluslararası organizasyonlarda başarılı olmak için daha çok çaba sarf etmeleri gerektiği sonucuna ulaşılmıştır. Türkiye'de Spor Toto Süper Lig'in ekonomik büyüklüğü Türkiye futbol liginin 2 milyar doları yayın geliri olmak üzere toplamda 3 milyar dolarlık ekonomik büyüklüğe sahiptir (Milliyet, 2018). Bu ekonomik büyüklüğün devamlılığı ülke ekonomisi açısından düşünüldüğünde spor turizmine olumlu yönde yansımaları olacaktır.

Karakoç (2011), 2010 Dünya Basketbol Şampiyonasının Spor Turizmi ve Ekonomik Etkilerini incelemiştir. 2011 yılında yapılan bu araştırmanın örneklem grubunu 2010 Dünya Şampiyonasını izlemek amacıyla Türkiye'ye gelen 400 yabancı turist oluşturmaktadır. İlgili araştırmada sonuç olarak; Şampiyonaya spor turisti olarak katılan kadın bireylerin çoğunlukla spor turizmini araç olarak kullandığı ve ülkemizdeki tarihi yerlere kültür turizmine katkı yapacak şekilde ziyaretlerde bulunduklarına ulaşılmıştır. Aynı zamanda düzenlenen bu turnuvanın Türkiye ekonomisine kayda değer bir katkı sağlamadığı sonucuna ulaşılmıştır.

Ataçocuğu (2008) tarafından yapılan bir araştırmada, Sidney ve Atina Olimpiyat Oyunlarında ev sahibi ülkelerin gayrisafi yurtiçi hâsılalarının artmasına katkıda bulunurken Atlanta Olimpiyatları için aynı durum söz konusu olmadığı sonucuna ulaşılmıştır. Düzenlenen bu turnuvalar ülkelerin işsizlik oranlarının azalmasına katkı sağlamıştır.

Türkiye Spor Turizmi Çalıştayı bilgi notlarına göre, Türkiye coğrafi yapısı ve iklim özelliklerinden dolayı spor turizmi potansiyeli yüksek olan ülkeler arasında yer almaktadır. Bu potansiyele rağmen, Türkiye'de spor turizminin yapısını ele aldığımızda, yapılan sporlar arasında ağırlıklı olarak futbol ve golf sporunun olduğu görülmektedir. Dünyanın en önemli turizm destinasyonları içerisinde yer alan Antalya'da 2019 yılında golf turizminden yılda 120 bin kişiden ortalama 135 milyon Euro'nun ülke ekonomisine girdisi sağlamaktadır (Hürriyet, 2019). Ayrıca, Türkiye dört mevsim spor yapılmasına elverişli iklim koşullarına, deniz, dağ, orman, su altı, nehir, 
Duman S, Şahin HM, Uluç EA, Bulut Ç. (2021). Spor Turizminin Türkiye Açısından Ekonomik Boyutu. Gaziantep Üniversitesi Spor Bilimleri Dergisi, 6(4), 367-383.

göl, kanyon, mağara gibi coğrafi zenginliklerine, alternatif spor faaliyetlerine uygun zemine sahiptir. Ege bölgesi içerisinde yer alan ve en gözde turizm bölgeleri olarak görülen Bodrum, Marmaris, Akyaka ve Fethiye'de çok sayıda yelken, kite surf ve yat yarışına ev sahipliği yapılmaktadır. Bu bölgelerde düzenlenen etkinliklere Türkiye'nin yanı sıra dünyanın birçok ülkesinden katılan sporcular hem denizde mücadele vermekte hem de bölgenin tanıtımını yaparak ekonomisine katkı sağlamaktadırlar.

Spor Turizminin Türkiye açısından ekonomik boyutunun incelendiği bu araştırmada, konu ile ilgili yapılan araştırmalar; Spor ve turizmin birbirine entegre edilmiş bir kavram olduğu, turizmde meydana gelen her bir olayın spor turizmini etkiyebileceği gibi ülke ekonomisini de etkilediği sonucuna ulaşılmıştır. Ülkemizde düzenlenen organizasyonlar ve organizasyonlara katılım sağlayan bireylerin o bölgeden memnun kaldığı zaman o ülkeyi tekrar ziyaret etme olasılıklarının artması hem de gelen turistlerin kendi ülkelerine geri dönüş yaptıkları zaman ülkenin tanıtımını yapmaları olasıdır. Bu durumun turizm gelirlerini artıracağı gibi ülke ekonomisine de olumlu yönde katkı sağlayacağı düşünülmektedir.

\section{Kaynaklar}

Akyol, C. ve Akkaşoğlu, S. (2021). Alternatif turizm türlerinin destinasyonlara katkısı; Artvin ve spor turizmi. Journal of Humanities and Tourism Research, 11 (1), 177-194.

Alaeddinoğlu, F. ve Komşu, M. K. (2017). TRB2 Bölgesi Turizminin Rekabet Gücü Üzerine Bir Alan Araştırması, Karabük Üniversitesi Sosyal Bilimler Enstitüsü Dergisi, 7 (2), 428-448.

Arabacı, H. (2018). Turizm Sektörünün Ekonomik Büyümeye Etkisi Üzerine Teorik Bir Inceleme. Balkan ve Yakın Doğu Sosyal Bilimler Dergisi, 4(3), 104-109.

Aracı, H. (1999). Öğretmen ve Okullarda Beden Eğitimi. Ankara: Bağırgan Yayınevi. Ataçocuğu, M. (2008). Olimpiyat Oyunlarının Ev Sahibi Ülke ve Kente Ekonomik Etkilerinin Araştırıması. Yayımlanmamış Yüksek Lisans Tezi, Muğla Üniversitesi Sosyal Bilimler Enstitüsü, Muğla.

Aymankuy, Y. (2013). Kongre Turizmi ve Fuar Organizasyonları. Ankara: Detay Yayıncilık.

Barutçugil, G. (1989). Turizm İşletmeciliği. İstanbul: Beta Yayınları.

Baykul, A. ve Maden, S. I. (2017). Bölgesel Kalkınma ve Turizm İlişkisi: Tr61 Bölgesi Üzerine Bir Değerlendirme. Uluslararası Global Turizm Araştırmaları Dergisi, 1(2), 65-73. 
Duman S, Şahin HM, Uluç EA, Bulut Ç. (2021). Spor Turizminin Türkiye Açısından Ekonomik Boyutu. Gaziantep Üniversitesi Spor Bilimleri Dergisi, 6(4), 367-383.

Beyazgül, M., Karadeniz, E. ve Güdük T. (2019). Futbolda Turizmin Ekonomik Etkileri ve Ülkeler Açısından Önemi. 3. Uluslararası Turizmin Geleceği Kongresi: İnovasyon, Girişimcilik ve Sürdürebilirlik Kongresi (Futourism 2019). Mersin Üniversitesi Yayınları.

Can, İ. I. (2020). Türkiye Ekonomisinde Turizmin Öncü Sektör Olmasını Sağlayacak Uygulamalar: Ulusal Paydaşların Görüşlerine İlişkin Bir Araştırma. Yayımlanmamış Yüksek Lisans Tezi, İstanbul Üniversitesi, Sosyal Bilimler Enstitüsü, Turizm İşletmeciliği Anabilim Dalı, İstanbul.

Çuhadar, M. (2006). Turizm Sektöründe Talep Tahmini için Yapay Sinir Ağları Kullanımı ve Diğer Yöntemlerle Karşılaştırmalı Analizi (Antalya Illinin Dış Turizm Talebinde Uygulama). Yayımlanmamış Doktora Tezi, Süleyman Demirel Üniversitesi, Isparta.

Delpy L. (1998). "Editorial", Journal Of Vacation Marketing, 4(1), (1998).

Dilber, İ. (2007). Turizm Sektörünün Türkiye Ekonomisi Üzerindeki Etkisinin Girdi-Çıktı Tablosu Yardımıyla Değerlendirilmesi. Yönetim ve Ekonomi, 14(2), 205-220.

Dünya Atlası. (2018). Türkiye'nin Turizm Potansiyeli ve Varlıkları- Dünya Atlası Erişim

Adresi https://www.dunyaatlasi.com/turkiyenin-turizm-potansiyeli-ve-varliklari/ Erişim Tarihi 07.07.2021.

Dünya Bankası Veri Tabanı (2020). Erişim Adresi https://www.worldbank.org/en /where-we-work Erişim Tarihi 07.07.2021.

Dünya Turizm Konseyi (2018). The economic impact of travel \& tourism. Erişim Adresi https://www.wttc.org/-/media/files/.../world2018.pdf Erişim Tarihi 07.07.2021.

Dünya Turizm ve Seyehat Acenteleri Konseyi (2020). Travel \& Touissm Global Economic Impact \& Trends 2020 - May 2020. The World Travel \& Tourism Council.

Gibson H.J. (1998). "Active Sport Tourism: Who Participates?", Leisure Studies, 17:2. Grössing, S. (1991). Beden ve Spor Hareket 1. Eğitim Kurumlarında Beden Eğitimi ve Spor Sempozyumu. Ankara: Milli Eğitim Basımevi.

Güdük, T. (2019). Mersin İlinin Spor Turizm Potansiyelinin Swot Analizi Yöntemiyle İncelenmesi. Yayımlanmamış Yüksek Lisans Tezi, Mersin Üniversitesi, Sosyal Bilimler Enstitüsü, Turizm İşletmeciliği Anabilim Dalı, Mersin.

Gündoğdu, N. (2001). Olimpizm ve Olimpiyat Organizasyonları. İstanbul. Hazar, A. (2007). Spor ve Turizm. Ankara: Detay Yayıncılık. 
Duman S, Sahin HM, Uluç EA, Bulut Ç. (2021). Spor Turizminin Türkiye Açısından Ekonomik Boyutu. Gaziantep Üniversitesi Spor Bilimleri Dergisi, 6(4), 367-383.

Holloway, J. C., Humphreys, C. ve Davidson, R. (2009). The Business of Tourism, eight

Hürriyet (2019) Golf Turizminin Ekonomiye Katkısı Yılda 135 milyon avro. Erişim Adresi https://www.hurriyet.com.tr/ekonomi/golf-turizminin-ekonomiye-katkisiyilda-135-milyon-avro-41285929 Erişim Tarihi 07.07.2021.

İçöz, O. ve Kozak, M. (2002). Turizm Ekonomisi. Ankara: Turhan Kitabevi.

Karakoç, B. (2011). 2010 Dünya Basketbol Şampiyonasının Spor Turizmi ve Ekonomik Etkileri Açısından İncelenmesi. Yayımlanmamış Yüksek Lisans Tezi, Muğla Üniversitesi, Sosyal Bilimler Enstitüsü, Beden Eğitimi ve Spor Anabilim Dalı. Muğla.

Kasap, A. A. ve Faiz, G. (2008). Bir Endüstri Olarak Golf; Ekonomik Analizi, Müşteri Portföy Analizi ve Dünyadaki Çevresel Yaklaşımlar. İstanbul: Türkiye Golf Federasyonu Yayınları.

Kuburlu, C. (2017). “İşte Türkiye'nin Spor Turizmi Hacmi”. Erişim Adresi http://www.turizmaktuel.com/haber/600-bin-turist-spor-icin-geldi Erişim Tarihi 06.07.2021.

Kurtzman, J. ve Zauhar, J. (2003). "A Wave in Time-The Sports Tourism Phenomena". Journal of Sport \& Tourism, 8(1), 35-47.

Miçoğulları, B. O. (2004). Türkiye Stratejisinin Belirlenmesi ve Geliştirilmesi. Yayımlanmamış Yüksek Lisans Tezi, Muğla Sıktı Koçman Üniversitesi, Muğla.

Milliyet, (2018). Erişim Adresi http://www.milliyet.com.tr/skorer/3-bine-yakin-takimantalyada-kampyapacak-2780605 Erişim Tarihi 07.07.2021.

Orel, F. ve Yavuz, C. (2003). Rekreasyonel Turizmde Müşteri Potansiyelinin Belirlenmesine Yönelik Bir Pilot Çalışma. Çukurova Üniversitesi, Sosyal Bilimler Enstitüsü Dergisi, 11(11).

Özcan, Ş.S. (2021). Turizm ve Ekonomik Büyüme İlişkisi: Üst-Orta Gelirli Ülkeler Üzerine Paralel Veri Analizi. Yayımlanmamış Yüksek Lisans Tezi, Hacettepe Üniversitesi, Sosyal Bilimler Enstitüsü, İşletme Anabilim Dalı, Turizm İşletmeciliği Uzmanlığı Bilim Dalı, Ankara.

Özdemir, B.U. (2020). Fırat Üniversitesi Spor Bilimleri Fakültesinde Eğitim Gören Öğrencilerin Spor Turizmine Yönelik Tutumlarının İncelenmesi. Yayımlanmamış Yüksek Lisans Tezi, Fırat Üniversitesi, Sağlık Bilimleri Enstitüsü, Beden Eğitimi ve Spor Anabilim Dalı. Elâzığ. 
Peric, M. (2010). "Sports Tourism and System of Experiences". Tourism and Hospitality Management, 16(2), 197-206.

Rahmalaroğlu, S. Y. (2019). Dünya'da ve Türkiye'de Golf Turizmi: Antalya Destinasyonu Örneği. Yayımlanmamış Yüksek Lisans Tezi, Akdeniz Üniversitesi, Sosyal Bilimler Enstitüsü, Turizm İşletmeciliği Anabilim Dalı, Antalya.

Spor Turizmi Çalıştayı Bilgi Notları Erişim Adresi https://turkiyesporturizmicalistayi.gsb.gov.tr/Sayfalar/3500/3489/i -classfas-faquestion-circle-i- bilgi-notlari.aspx Erişim Tarihi 07.07.2021.

Stephen, D.R. (2001). Developing Sport Tourism Natıonal Laboratoryf orand Commerce.

Şahbaz, A. ve Mızırak, Z. (2017). Turizm Gelirleri ve Doğrudan Yabancı Yatırımlar Arasındaki İlişki: Türkiye Örneği. KMÜ Sosyal ve Ekonomik Araştırmalar Dergisi, 19(32), 107-114.

Şebin, K. (2018). Spor ve Turizm İlişkisi. Ankara: Nobel Yayıncılık.

Taleghani, G. R. ve Ghafary, A. (2014). Providing A Management Model for the Development of Sport Tourism, Procedia- Social and Behavioral Sciences, 120, 289-298.

Toromanlı, A. (2014). Spor Turizminde Olimpiyat Oyunları ve Spor Turizmin Gelişimine Katkıları. Yayımlanmamış Yüksek Lisans Tezi, Maltepe Üniversitesi, Sosyal Bilimler Enstitüsü, İşletme Anabilim Dalı, İstanbul.

Tourism Review News. (2010). "Sport Tourism is Multi-million Dollar Industry". Erişim Adresi https://www.tourism-review.com/travel-tourism-magazine-sports-tourism worldwidephenomenon-article1330 Erişim Tarihi 07.07.2021.

Turgut, F. (2019). Turizm Eğitimi ile Spor Bilimleri Eğitimi Lisans Öğrencilerinin Spor Turizmine Yönelik Tutumlarının İncelenmesi (Düzce Üniversitesi Örneği). Yayımlanmamış Yüksek Lisans Tezi, Düzce Üniversitesi, Sosyal Bilimler Üniversitesi, Düzce.

Türkiye Seyahat Acenteleri Birliği (2015). "Spor Turizmi Raporu". Erişim Adresi http://www.tursab.org.tr/dosya/12195/ tursab-sporturizmi raporu_12195_ 5670173. pdf Erişim Tarihi 06.07.2021.

Türkiye Seyahat Acenteleri Birliği (2020). Erişim Adresi https://www.tursab.org.tr/ Erişim Tarihi 07.07.2021. 
Duman S, Şahin HM, Uluç EA, Bulut Ç. (2021). Spor Turizminin Türkiye Açısından Ekonomik Boyutu. Gaziantep Üniversitesi Spor Bilimleri Dergisi, 6(4), 367-383.

Türkiye Seyahat Acenteleri Birliği Raporu (2014). 8. TURSAB Spor Turizmi Raporu Erişim Adresi https://tursab.org.tr./dosya/12195/ tursab/ sportur izmiraporu _12195_5670173.pdf Erişim Tarihi 07.07.2021.

Usta, Ö. (2009). Turizm Genel ve Yapısal Yaklaşım. Ankara: Detay Yayıncılık.

Yeşil, M. (2015). Antalya'da Spor Turizmi: Mevcut Durumun Tespiti. Yayımlanmamış Yüksek Lisans Tezi, Akdeniz Üniversitesi, Sosyal Bilimler Enstitüsü, İşletme Anabilim Dalı, Antalya.

Zengin, B. (2006). Turizm Coğrafyası. Değişim Yayınları. 